\title{
PENGUKURAN KINERJA BANK SYARIAH DENGAN METODE RGEC
}

\author{
Umiyati dan Queenindya Permata Faly \\ UIN Syarif Hidayatullah Jakarta \\ Email: umiyati@uinjkt.ac.id
}

\begin{abstract}
This research is on purpose to discover any significant differences on Panin Syariah Bank work performance before and after go public using the RGEC Method, and also to find out how large the difference performance of it. Data used in this research was a secondary data which took from financial report quarterly era 2013-2014 that has been published. Meanwhile, that method used was a comparison method using statistic non parametric test equipment two related samples (wilcoxon test). The result in this research shows that variable of capital adequacy ratio (CAR) had a significant difference, because of having a sig. value $<0,05$. While other variable (1.e. Non Performing Financing (NPF), Financing to Deposit Ratio (FDR), Return On Asset (ROA), Return On Equity (ROE), Net Interest Margin (NIM) or Net Operating Margin (NOM), and Good Corporate Governance.
\end{abstract}

Keywords: RGEC, Comparison, Go Public, NPF, FDR, ROA, ROE, NIM, CAR

\section{PENDAHULUAN}

Bank syariah adalah bank yang beroperasi sesuai dengan prinsip-prinsip yang ada dalam ajaran Islam, berfungsi sebagai badan usaha yang menyalurkan dana dari dan kepada masyarakat atau sebagai lembaga perantara keuangan. Islamic banking merupakan unit sistem ekonomi Islam yang beroperasi dengan doktrin dan larangan terhadap praktik riba. Perbankan Islam memiliki peran strategis dalam meningkatkan kesejahteraan umat, melalui proses intermediasi kegiatan penghimpunan dan penyaluran dana maupun penyediaan jasa keuangan lainnya, berlandaskan prinsip-prinsip syariah. Ketika sistem perbankan konvensional tidak stabil karena sistem moneter dan memerlukan biaya yang begitu besar untuk mempertahankannya, perbankan syariah justru mampu menyelamatkan sebagian ekonomi umat. Kemampuan survival perbankan Islam dalam era krisis, telah menarik banyak perhatian para banker konvensional yang kemudian membuka kantor-kantor cabang bank Islam (Rifai, 2008).

Sebagai sebuah lembaga keuangan yang masih relatif baru, keberadaan bank syariah merupakan keberhasilan dan kebanggaan tersendiri bagi umat Islam yang konsisten melaksanakan ajaran agama (Muhammad, 2005).

Oleh karena itu industri perbankan di Indonesia semakin diramaikan dengan adanya bank syariah yang tumbuh pesat, yang menawarkan produk keuangan dan investasi dengan cara berbeda dengan bank konvensional. 
Salah satu faktor yang mempercepat pertumbuhan industri perbankan saat ini adalah strategi manajemen bank dalam melakukan ekspansi yaitu dengan cara go public yang artinya menjual sebagian sahamnya kepada publik dan mencatatkan sahamnya di Bursa Efek Indonesia. Pada lembaga keuangan perbankan syariah, satu-satunya bank yang melakukan pencatatan saham di bursa efek adalah Bank Panin Syariah pada tahun 2014. Dalam situs resmi Bursa Efek Indonesia menjelaskan manfaat yang dapat diperoleh perusahaan ketika menjadi perusahaan yang go public melalui pencatatan perdana saham (initial public offering), diantarnya yaitu: memperoleh sumber pendanaan baru, memberikan competitive advantage untuk pengembangan usaha, melakukan merger atau akuisisi perusahaan lain dengan pembiayaan melalui penerbitan saham baru, peningkatan kemampuan going concer, meningkatkan citra perusahaan, dan meningkatkan nilai perusahaan.

Berdasarkan pemaparan diatas, apabila bank akan melakukan pencatatan sahamnya di bursa efek, diperlukan kondisi yang sehat untuk menjaga loyalitas dan kepercayaan pemegang saham maupun masyarakat (nasabah) dalam menghimpun dan menyalurkan dana serta menyediakan jasa. Selain memerlukan kondisi yang sehat, bank juga harus memiliki kecukupan modal dan konsisten dalam peningkatan laba sekurang-kurangnya dalam jangka lima tahun.

Menurut UU Nomor 21 Tahun 2008 tentang perbankan syariah, bank wajib memelihara tingkat kesehatannya. Kesehatan bank harus dipelihara dan/atau ditingkatkan agar kepercayaan masyarakat terhadap bank dapat tetap terjaga. Selain itu, tingkat kesehatan bank digunakan sebagai salah satu sarana dalam melakukan evaluasi terhadap kondisi dan permasalahan yang dihadapi bank serta menentukan tindak lanjut untuk mengatasi kelemahan atau permasalahan bank, baik berupa corrective action oleh bank maupun supervisory action oleh Otoritas Jasa Keuangan.

Kesehatan bank yang merupakan cerminan kondisi dan kinerja bank merupakan sarana bagi otoritas pengawas dalam menetapkan strategi dan fokus pengawasan terhadap bank. Selain itu, kesehatan bank juga menjadi kepentingan semua pihak terkait, baik pemilik, pengelola (manajemen), dan masyarakat pengguna jasa Bank (Peraturan Otoritas Jasa Keuangan Nomor 8/POJK.03/2014).

Kebijakan tersebut pada dasarnya ditujukan untuk menciptakan dan memelihara kesehatan bank. Kesehatan atau kondisi keuangan dan non keuangan bank merupakan kepentingan semua pihak terkait tersebut untuk mengevaluasi kinerja bank dalam menerapkan prinsip kehati-hatian, kepatuhan terhadap ketentuan yang berlaku dan manajemen risiko.

Industri perbankan di Indonesia menguasai sekitar 93\% dari total asset industri keuangan. Dalam kondisi yang demikian, apabila lembaga perbankan tidak sehat dan tidak dapat berfungsi secara optimal, maka dapat dipastikan akan berakibat pada terganggunya kegiatan perekonomian (Husein, 2003 dalam Marnov, 2009). 
Perkembangan industri perbankan, terutama produk dan jasa yang semakin kompleks dan beragam akan meningkatkan eksposur risiko yang dihadapi bank. Perubahan eksposur risiko bank dan penerapan manajemen risiko akan mempengaruhi profil risiko bank yang selanjutnya berakibat pada kondisi bank secara keseluruhan(Peraturan Otoritas Jasa Keuangan Nomor 8/POJK.03/2014).

Apabila suatu sistem perbankan dalam kondisi yang tidak sehat, maka fungsi bank sebagai lembaga intermediasi tersebut, dan alokasi serta penyediaan dana dari perbankan untuk kegiatan investasi dan membiayai sektor-sektor yang produktif dalam perekonomian menjadi terbatas. Sistem perbankan yang tidak sehat juga akan mengakibatkan lalu lintas pembayaran yang dilakukan oleh sistem perbankan tidak lancar dan efisien. Selain itu, sistem perbankan yang tidak sehat juga akan menghambat efektivitas kebijakan moneter (Bank Indonesia, 2003).

Memburuknya kondisi tingkat kesehatan perbankan disebabkan oleh banyak faktor yang sangat beragam. Faktor utama yang hampir dihadapi seluruh perbankan adalah membengkaknya jumlah kredit yang bermasalah dan kredit macet. Semakin banyaknya kredit bermasalah dan kredit macet yang muncul akhir-akhir ini, semakin memperkeruh suasana bahkan menjadi dampak kesulitan perbankan saat ini. Akhir-akhir ini istilah bank sehat atau tidak sehat semakin populer. Berbagai kejadian aktual, tentang perbankan seperti merger dan likuidasi selalu dikaitkan dengan kesehatan bank. Oleh karenanya sebuah bank tentunya memerlukan suatu analisis untuk mengetahui kondisinya setelah melakukan kegiatan operasionalnya dalam jangka waktu tertentu. Analisis yang dilakukan berupa penilaian tingkat kesehatan bank. Kesehatan suatu bank adalah kemampuan suatu bank untuk melakukan kegiatan operasional perbankan secara normal dan mampu memenuhi semua kewajibannya dengan baik dengan cara-cara yang sesuai dengan peraturan perbankan yang berlaku (Wardani, 2009).

Berdasarkan PBI No. 13/1/PBI/2011 bank umum memiliki aturan baru mengenai penilaian tingkat kesehatan. Cakupan penilaiannya menggunakan pendekatan risiko dengan faktor-faktor yang dinilai antara lain Risk profile (Profil Risiko), Good Corporate Governance (GCG), Earnings (Rentabilitas), Capital (Permodalan). Penilaian tingkat kesehatan bank ini dikenal dengan metode RGEC, namun berdasarkan peraturan tersebut, metode ini hanya digunakan untuk bank umum konvensional. Sedangkan bank syariah hingga tahun 2013 masih menggunakan metode CAMELS (Capital, Assets, Management, Earnings, Liquidity, Sensitivity). Akan tetapi sejak diterbitkan POJK Nomor 8/03/2014 barulah bank syariah memiliki pedoman baru dalam penilaian tingkat kesehatannya yaitu dengan menggunakan metode RGEC, karena isi dari POJK Nomor 8/03/2014 hampir sama dengan PBI No.13/1/PBI/2011 yang menjelaskan bahwa penilaian tingkat kesehatan bank dilakukan dengan pendekatan risiko RBBR (Riskbased Bank Rating) dengan menggunakan faktor RGEC (Risk profile, GCG, Earnings, Capital). 
Dalam prospektus perusahaan yang akan go public, pada penelitian ini yaitu PT Panin Syariah, Tbk menyebutkan bahwa perusahaan setelah IPO (Initial Public Offering) akan mengalami peningkatan kinerja yang dapat dilihat dari penggunaan dana dimana dana yang diperoleh dari hasil penjualan saham sekitar $80 \%$ akan digunakan sebagai modal kerja guna memperkuat struktur pendanaan jangka panjang, serta sekitar $20 \%$ untuk pengembangan jaringan termasuk didalamnya infrastruktur perseroan. Hal ini juga disebutkan dalam teori menurut Tandelilin (2010) dimana investasi sebagai komitmen atas sejumlah dana atau sumber daya lainnya yang dilakukan pada saat ini, dengan tujuan memperoleh keuntungan dimasa depan. Dengan meningkatnya daya tarik seorang terhadap investasi memicu sebuah perusahaan untuk melakukan Initial Public Offering dengan harapan perusahaan setelah pelaksanaan IPO, dapat memberikan peluang yang besar untuk jangka panjang bagi perusahaan seperti peningkatan dari segi kinerja perusahaan/manajemen, modal yang dimiliki, laba yang diperoleh, kinerja keuangan, dan kualitas.

Namun teori tersebut bertolak belakang dengan fenomena yang terjadi bahwa perusahaan setelah melakukan IPO (Initial Public Offering) mengalami penurunan kinerja. Hal ini didukung berdasarkan beberapa penelitian diantaranya Perdana (2010) melakukan penelitian tentang kinerja keuangan perusahaan sebelum dan sesudah go public studi kasus pada PT. Surya Citra Medika Tbk. alat analisis yang digunakan yaitu rasio likuiditas, aktivitas, leverage, dan profitabilitas. Penelitiannya menggunakan time series analysis. Hasilnya menunjukkan bahwa secara keseluruhan kinerja keuangan PT. Surya Citra Medika Tbk mengalami penurunan pasca go public apabila dibandingkan dengan periode sebelum go public.

Penelitian yang dilakukan oleh Gumanti (2007) dalam Ikhsan dengan periode pengamatan tahun 1995 dan 1996 dengan objek seluruh perusahaan non keuangan yang telah go public menggunakan rasio operating performance dengan indikatornya yaitu operating return on asset, operating cash flow, salesh growth dan total asset turn over, menunjukkan bahwa perusahaan yang baru go public di pasar modal Indonesia tidak mampu mempertahankan kinerja operasinya dalam jangka waktu sampai dengan tiga tahun setelah go public. Penelitian yang sama dilakukan oleh Adhisyahfitri Evalina Ikhsan dengan periode yang berbeda yaitu 2001-2004 dimana hasil dari penelitian ini menunjukkan bahwa terdapat perbedaan kinerja perusahaansebelum dan sesudah melakukan IPO dan membuktikan bahwa adanya penurunan kinerja perusahaan sesudah melakukan IPO yang dilihat dari rasio Operating Return On Asset, Operating Cash Flow, Sales Growth, Total Asset Turn Over, Cash Flow To Net Income dan Cash Flow Return On Sales. 


\subsection{KINERJA KEUANGAN BANK SYARIAH}

Kinerja bank secara keseluruhan merupakan gambaran prestasi yang dicapai bank dalam operasionalnya, baik menyangkut aspek pemasaran, keuangan, penghimpunan, dan penyaluran dana, serta teknologi maupun sumber daya manusia. Kinerja keuangan bank merupakan gambaran kondisi keuangan bank pada suatu periode tertentu baik menyangkut aspek penghimpunan dana maupun penyaluran dana yang biasanya diukur dengan indikator kecukupan modal, likuiditas, dan profitabilitas bank (Jumingan, 2006).

Dalam Signalling Theory menjelaskan bahwa, pentingnya pengukuran kinerja suatu perusahaan dan juga alasan perusahaan menyajikan informasi untuk pasar modal. Dalam teori ini membahas bagaimana seharusnya signalsignal keberhasilan atau kegagalan manajemen (agen) disampaikan kepada pemilik. Teori signal menjelaskan bahwa pemberian signal dilakukan oleh manajemen untuk mengurangi informasi asimetris.

Menurut Kusuma (2006) pada signalling theory terdapat motivasi manajemen dalam menyajikan informasi keuangan yang diharapkan dapat memberikan sinyal kemakmuran kepada pemilik ataupun pemegang saham. Publikasi laporan keuangan tahunan yang disajikan oleh perusahaan akan dapat memberikan signal pertumbuhan dividen maupun perkembangan harga saham perusahaan.

Laporan keuangan yang mencerminkan kinerja yang baik merupakan sinyal bahwa perusahaan telah beroperasi dengan baik, namun sebagai salah satu alat ukur yang digunakan perusahaan dalam mengukur kinerja dan juga untuk menarik calon investor, laporankeuangan seringkali dibuat sedemikian rupa untuk menampilkan angka yang diinginkan oleh manajemen melalui berbagai tindakan manipulasi. Hal ini dilakukan pada laporan laba perusahaan, karena laba sangat rentan terhadap perubahan metoda akuntansi. Hal ini sesuai dengan teori signal yang menunjukkan kecenderungan adanya asimetri informasi antara pemilik perusahaan dan investor (Jensen dan Meckling, 1976 dalam Meythi, 2013).

Laporan keuangan dapat dianalisis dengan menggunakan alat ukur yaitu rasio keuangan. Rasio dapat menggambarkan suatu hubungan antara jumlah tertentu dengan jumlah yang lainnya. Analisis yang dilakukan terhadap laporan keuangan tersebut kemudian dapat digunakan sebagai gambaran tentang kondisi perusahaan. Rasio keuangan digunakan untuk membandingkan angka-angka yang ada dalam laporan keuangan dengan cara membagi suatu angka dengan angka lainnya. Perbandingan dapat dilakukan antara satu komponen dengan komponen dalam satu laporan keuangan atau antar komponen yang ada diantara laporan keuangan. Kemudian angka yang diperbandingkan dapat berupa angka-angka dalam satu periode maupun beberapa periode (Kasmir, 2010).

Beberapa rasio keuangan yang dapat digunakan dalam mengukur kinerja bank adalah sebagai berikut: NPF (Non Performing Financing), FDR (Financing to Deposit Ratio), ROA (Return on Asset), ROE (Return on Equity), NIM (Net InterestMargin, CAR (Capital Adequacy Ratio), dan GCG (Good Corporate Governance). 


\subsection{IPO (INITIAL PUBLIC OFFERING)}

Di pasar modal Indonesia, istilah penawaran umum perdana atau IPO (Initial Public Offering) saham atau disebut juga sebagai go public dapat didefinisikan sebagai kegiatan untuk pertama kalinya suatu saham perusahaan ditawarkan atau dijual kepada publik. Selain saham, istilah IPO juga dapat dikaitkan dengan penawaranpenjualan obligasi perusahaan kepada publik. Namun untuk go public, istilah tersebut hanya berlaku untuk IPO saham (Inayah, 2014).

Dalam dunia perbankan syariah di Indonesia, sejauh ini hanya Bank Panin Syariah yang telah melakukan IPO (Initial Public Offering) dan melisting sahamnya di Bursa Efek Indonesia. Oleh karena itu, Bank Panin Syariah telah mengukir sejarah baru dalam dunia perbankan syariah sebagai bank syariah pertama yang telah melakukan penawaran saham kepada masyarakat secara luas.

Hal ini menunjukkan adanya hubungan yang saling mempengaruhi antara pasar uang dan pasar modal dimana bank merupakan peserta dalam pasar uang dan pasar modal. Sebagai pihak yang menanamkan dana dengan tujuan yaitu untuk memperoleh penghasilan dengan tingkat suku bunga tertentu. Ketiga lembaga tersebut saling terkait karena pasar uang dan pasar modal merupakan wadah untuk lembaga - lembaga seperti bank untuk menanamkan dana atau membutuhkan dana dengan tujuan untuk likuiditas. Selain untuk fungsi tersebut, bank memanfaatkan proses IPO sebagai fasilitas pembiayaan baik dalam hal operasional ataupun permodalan. sehingga antara pasar uang dan pasar modal menunjukkan adanya hubungan saling keterkaitan antara satu dengan yang lain.

\subsection{TINGKAT KESEHATAN BANK}

Kesehatan bank merupakan kemampuan bank untuk melakukan kegiatan operasional perbankan secara normal dan mampu memenuhi kewajiban dengan baik dan dengan cara-cara yang sesuai peraturan perbankan yang berlaku (Santoso, 2006:51 dalam Lasta, Heidy, dkk., 2014).

Sedangkan menurut Kasmir (2010) tingkat kesehatan bank dapat diartikan sebagai kemampuan suatu bank untuk melakukan kegiatan operasional perbankan secara normal dan mampu memenuhi semua kewajibannya dengan baik dengan cara-cara yang sesuai dengan peraturan perbankan yang berlaku.

Dalam Surat Edaran (SE) Bank Indonesia No.13/24/DPNP tanggal 25 Oktober 2011 tentang Penilaian Tingkat Kesehatan Bank Umum tersebut merupakan petunjuk pelaksanaan dari Peraturan Bank Indonesia No.13/1/PBI/2011, yang mewajibkan Bank Umum untuk melakukan penilaian sendiri (self assessment) tingkat kesehatan bank dengan menggunakan pendekatan risiko (Risk-based Bank Rating) baik secara individual maupun secara konsolidasi. Selain itu, dalamSurat Edaran (SE) tersebut terdapat prinsip- prinsip yang digunakan untuk menilai tingkat kesehatan bank, yaitu sebagai berikut berorientasi risiko, materialitas dan signifikansi, komprehensif dan terstruktur. 


\subsection{METODE RGEC}

Mengingat pesatnya perkembangan sektor perbankan dan perubahan kompleksitas usaha serta profil risiko bank, dan juga adanya perubahan metodologi dalam penilaian kondisi bank yang diterapkan secara Internasional. Pengalaman dari krisis keuangan global telah mendorong perlunya peningkatan efektifitas penerapan manajemen risiko dan GCG. Tujuannya adalah agar bank mampu mengidentifikasi masalah secara lebih dini, melakukan tindak lanjut perbaikan yang sesuai dan lebih cepat, serta menerapkan GCG manajemen risiko yang lebih baik sehingga bank lebih tahan dalam menghadapi krisis (SE Bank Indonesia No. 13/24/DPNP tahun 2011). Kinerja bank atau tingkat kesehatan bank syariah dapat dinilai dengan metode RGEC.

Gambar 1. Siklus Periode Penilaian Tingkat Kesehatan Bank

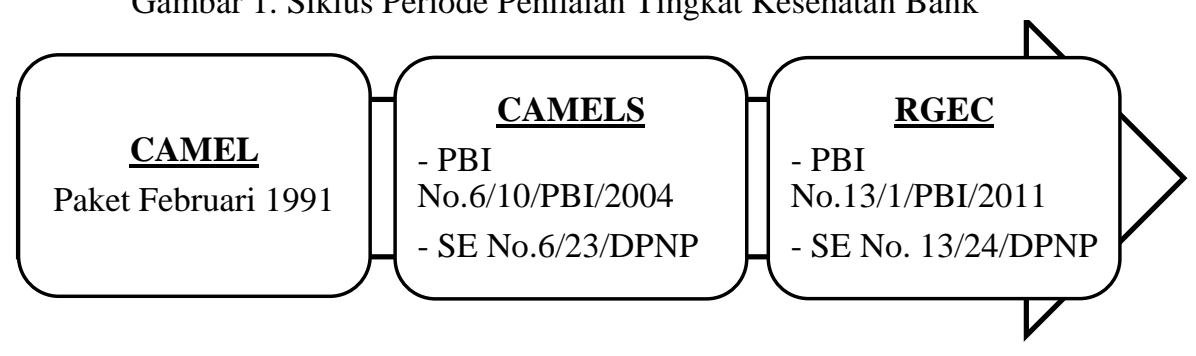

Menurut Mutia (2014) menjelaskan bahwa metode CAMEL pertama kali diperkenalkan di Indonesia sejak dikeluarkannya Paket Februari 1991 mengenai sifat-sifat kehati-hatian bank. Paket tersebut dikeluarkan sebagai dampak kebijakan Paket Kebijakan 27 Oktober 1988 (Pakto 1988). CAMEL berkembang menjadi CAMELS pada tanggal 1 Januari 1997 di Amerika. CAMELS berkembang di Indonesia pada akhir tahuan 1997 sebagai dampak dari krisis ekonomi dan moneter.

Analisis CAMELS digunakan untuk menganalisis dan mengevaluasi kinerja keuangan bank umum di Indonesia. Analisis CAMELS diatur dalam Peraturan Bank Indonesia Nomor 6/10/PBI/2004 tentang sistem penilaian Tingkat Kesehatan Bank Umum dan Peraturan Bank Indonesia Nomor 9/1/PBI/2007 tentang Sistem Penilaian Tingkat Kesehatan Bank Umum Berdasarkan Prinsip Syariah.

Kemudian dikeluarkan PBI No. 13/1/PBI/2011 dan SE BI No.13/24/DPNP yang berlaku per Januari 2012 menggantikan penilaian kesehatan bank dengan metode CAMELS dengan metode RGEC. Metode CAMELS tersebut sudah diberlakukan selama hampir delapan tahun sejak terbitnya PBI No. 6/10/PBI/2004 dan SE No.6/23/DPNP. Dengan terbitnya PBI dan SE terbaru ini, metode CAMELS dinyatakan tidak berlaku lagi, diganti dengan model baru yang mewajibkan Bank Umum untuk melakukan penilaian sendiri (self-assessment) Tingkat Kesehatan Bank dengan menggunakan pendekatan risiko RBBR (Risk-based Bank Rating) baik secara individual maupun secara konsolidasi.

Berdasarkan peraturan Bank Indonesia No.13/1/PBI/2011 tentang Penilaian Tingkat Kesehatan Bank Umum, Bank Indonesia telah menetapkan 
sistem penilaian Tingkat Kesehatan Bank berbasis risiko. Menurut POJK No. 8/POJK.3/2014 faktor-faktor penilaian dalam metode RGEC yaitu sebagai berikut:

1. Risk Profile (Profil Risiko)

Peraturan Bank Indonesia No.13/1/PBI/2011 Pasal 7 ayat 1 penilaian terhadap faktor profil risiko sebagaimana dimaksud dalam pasal 6 huruf a merupakan penilaian terhadap risiko inheren dan kualitas penerapan manajemen risiko dalam operasional bank.

\section{Good Corporate Governance (GCG)}

Penilaian terhadap faktor GCG dalam pendekatan RGEC didasarkan ke dalam tiga aspek utama yaitu, governance structure, governance process, dan governance output. (Lasta, dkk., 2014).

3. Earnings (Rentabilitas)

Rentabilitas merupakan kemampuan bank dalam menghasilkan laba dari aktifitas bisnis bank. Laba merupakan hal yang sangat penting, dengan laba yang dihasilkan dari suatu kegiatan bisnis mengindikasikan bahwa kinerja yang telah dilakukan adalah baik dan dapat meneruskan kelangsungan hidup bisnis itu sendiri (Arifin, 2009).

4. Capital (Permodalan)

Peraturan bank Indonesia No. 13/1/PBI/2011 Pasal 7 ayat 2 sebagaimana dimaksud dalam pasal 6 huruf d meliputi penilaian terhadap tingkat kecukupan permodalan dan pengelolaan permodalan. Capital Adequacy Ratio (CAR) adalah rasio kinerja bank untuk mengukur kecukupan modal yang dimiliki bank untuk menunjang aktiva yang mengandung atau menghasilkan risiko (Kasmir, 2009:198).

\section{METODE PENELITIAN}

Ruang lingkup penelitian ini adalah menganalisis perbandingan kinerja Bank Panin Syariah sebelum dan setelahgo public, dimana Bank Panin Syariah merupakan sampel dalam penelitian ini. Adapun periode yang digunakan adalah periode tahun 2013-2014, karena tahun 2013 merupakan periode dimana Bank Panin Syariah sebelum go public, dan 2014 merupakan periode setelah go public. Data yang digunakan dalam penelitian ini adalah laporan keuangan Bank Panin Syariah tahun 2013-2014 dan laporan GCG yang merupakan salah satu faktor dalam metode RGEC(Risk profile, Good Corporate Governance (GCG), Earnings, Capital).

Sampel dalam penelitian ini adalah Bank Panin Syariah. Adapun metode yang dipakai dalam penelitian ini adalah metode purposive sampling yaitu penarikan sampel dengan pertimbangan tertentu dan kriteria yang diterapkan terhadap elemen sampel. Adapun kriteria-kriteria yang dimaksud adalah: 
1. Bank Umum Syariah yang sudah terdaftar di BEI

2. Selama periode tahun 2013-2014 secara periodik mempublikasikan laporan keuangan dan laporan GCG bank.

Oleh karena itu, alasan peneliti menggunakan Bank Panin Syariah sebagai objek dalam penelitin ini, karena Bank Panin Syariah merupakan satu-satunya bank syariah yang telah mencatatkan sahamnya pada Bursa Efek Indonesia (BEI), dan mempublikasikan laporan keuangannya secara periodik.

Metode pengumpulan data yang digunakan adalah dengan menggunakan data Sekunder. Jenis penelitianini adalah penelitian kuantitatif dengan menggunakan pendekatan studi kasus (case study), serta metode yang digunakan dalam penelitian ini adalah metode komparatif yaitu metode yang digunakan dalam penelitian yang diarahkan untuk mengetahui apakah antara dua variabel ada perbedaan dalam suatu aspek yang diteliti. Dimana laporan keuangan bank dan laporan GCG Bank Panin Syariah pada periode sebelum dibandingkandengan periode setelah go publicmenggunakan rasio-rasio yang terdapat dalam metode RGEC.

Adapun alat uji statistik yang digunakan dalam penelitian ini adalah metode uji beda Wilcoxon Signed RanksTest yaitu uji non parametrik yang digunakanuntuk menganalisis data pada dua kelompok yang berkaitan, termasuk dalam kasus sebelum dan sesudah yang mana objek yang sama diamati pada dua kondisi yang berbeda (Black, 2003 dalam Kurniawan, Albert, 2011).

Metode ini biasanya digunakan pada data-data kualitatif (skala nominal dan ordinal) atau untuk data kuantitatif (skala rasio) yang tidak berdistribusi normal(Kurniawan, 2012). Sedangkan ciri-ciri wilcoxon test adalah: (1) level pengukuran data yang rendah yaitu ordinal (2) jumlah data biasanya kurang dari 30 sampel (3) ciri utamanya berasal dari satu populasi yang sama namun diberi dua perlakuan yang berbeda dan mempunyai hubungan (4) data berdistribusi tidak normal (Kurniawan, Albert, 2011: 105).

Variabel-variabel yang digunakan dalam penelitian ini adalah sebagai berikut Variabel dependent (Y) yaitu laporan Keuangan dan dan laporan GCG Bank Panin Syariah, sedangkan variabel indenpenden (X) yaitu NPF (Non Perfoming Financing) $)\left(\mathrm{X}_{1}\right)$, FDR (Financing to Deposit Ratio) $\left(\mathrm{X}_{2}\right)$, ROA (Return on Asset) $\left(\mathrm{X}_{3}\right)$, $\mathrm{ROE}$ (Return on Equity)( $\left.\mathrm{X}_{4}\right)$, NIM (Net Interest Margin) $\left(\mathrm{X}_{5}\right)$, CAR (Capital Adequacy Ratio) $\left(\mathrm{X}_{6}\right)$, GCG (Good Corporate Governance)

\section{HASIL DAN PEMBAHASAN}

\subsection{ANALISIS DESKRIPTIF ATAU COMPARING MEANS VARIABEL PENELITIAN SEBELUM DAN SETELAH GO PUBLIC}

Tabel 1. Descriptive Statistics Rasio Keuangan Bank Panin Syariah, Tbk Sebelum dan Setelah Go Public

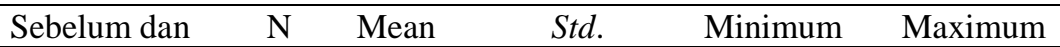




\begin{tabular}{lllllll}
\hline \multicolumn{2}{l}{ Setelah Go Public } & \multicolumn{5}{c}{ Deviation } \\
\hline \multirow{2}{*}{ NPF } & Sebelum & 4 & 0,7350 & 0,20469 & 0,56 & 1,01 \\
\cline { 2 - 7 } & Setelah & 4 & 0,5575 & 0,27945 & 0,29 & 0,94 \\
\hline \multirow{2}{*}{ FDR } & Sebelum & 4 & 111,84 & 15,06232 & 90,40 & 123,60 \\
\cline { 2 - 7 } & Setelah & 4 & 114,79 & 19,17760 & 94,04 & 140,48 \\
\hline \multirow{2}{*}{ ROA } & Sebelum & 4 & 2.0675 & 0.72780 & 1.03 & 2.72 \\
\cline { 2 - 7 } & Setelah & 4 & 1.7250 & 0.23245 & 1.45 & 1.99 \\
\hline \multirow{2}{*}{ ROE } & Sebelum & 4 & 8.0675 & 2.46754 & 4.44 & 9.97 \\
\cline { 2 - 7 } & Setelah & 4 & 6.3400 & 1.05688 & 5.27 & 7.66 \\
\hline \multirow{2}{*}{ NIM } & Sebelum & 4 & 5.4675 & 1.03552 & 4.26 & 6.49 \\
\cline { 2 - 7 } & Setelah & 4 & 5.2675 & 0.79504 & 4.10 & 5.88 \\
\hline \multirow{2}{*}{ CAR } & Sebelum & 4 & 22.6950 & 3.24754 & 19.75 & 27.09 \\
\cline { 2 - 6 } & Setelah & 4 & 27.1300 & 2.69363 & 25.52 & 31.15 \\
\hline & \multicolumn{5}{l}{ Sumber: data primer yang telah diolah } &
\end{tabular}

\subsubsection{Non Performing Financing (NPF)}

Pada tabel 1 dapat terlihat bahwa nilai rata-rata (mean) rasio NPF setelah go public sebesar $0,55 \%$ lebih kecil dibandingkan rasio NPF sebelum go public sebesar $0,73 \%$ yang artinya terjadi penurunan nilai rata-rata NPF sebesar 0,18. Persentase ini menunjukkan bahwa bank total pembiayaan bermasalah Bank Panin Syariah sebelum go public lebih besar dibandingkan setelah go public. Hal ini berarti NPF Bank Panin Syariah setelah go publiclebih baik dibandingkan sebelum go public. Namun, jika mengacu pada ketentuan bank indonesia yang menyatakan standar ideal NPF sebesar $<5 \%$ maka kinerja Bank Panin Syariah berada pada kondisi ideal.

\subsubsection{Financing to Deposit Ratio (FDR)}

Pada tabel 1 dapat terlihat bahwa nilai rata-rata (mean) rasio FDR setelah go public sebesar $114,79 \%$ lebih besar dibandingkan rasio FDR sebelum go public sebesar $111,84 \%$ yang artinya terdapat peningkatan nilai rata-rata FDR sebesar 2,95\%. Persentase dari peningkatan ini menunjukkan bahwa pembiayaan yang dilakukan oleh Bank Panin Syariah lebih besar dibandingkan dengan dana pihak ketiga. Hal ini dapat terjadi karena pada tahun 2014 Bank Panin Syariah telah melakukan go public sehingga modal yang dimiliki untuk melakukan pembiayaan jauh lebih besar dibandingkan dengan sebelum go public. Karena semakin besar FDR maka akan semakin besar kualitas dan tingkat likuiditasnya, selain itu FDR yang tinggi juga dapat memeperlihatkan bahwa Bank Panin Syariah kecil kemungkinannya memiliki dana idle fund yang cukup besar.Apabila jika mengacu pada ketentuan Bank Indonesia yang menyatakan standar ideal FDR sebesar 85$110 \%$ maka kinerja Bank Panin Syariah berada pada kondisi ideal.

\subsubsection{Return On Asset (ROA)}

Pada tabel 1dapat terlihat bahwa nilai rata-rata (mean) rasio ROA setelah go public sebesar $1,72 \%$ lebih kecil dibandingkan rasio ROA sebelum go public 
sebesar 2,06\% yang artinya terdapat perbedaan penurunan rata-rata ROA sebesar $0,34 \%$. Namun penurunan ini tidak memberikan dampak, karena perubahannya sangat kecil. Dan apabila mengacu pada penelitian sebelumnya yang dilakukan oleh Hari P (2014) tentang Pengukuran Kinerja Bank Syariah dengan Metode RGEC menunjukkan bahwa meskipun suatu bank mengalami penurunan kinerja, maka bank tersebut belum dapat diprediksi mengalami kebangkrutan selama parameter penanganan risiko bank tersebut sangat baik sehingga dapat mencegah atau meminimalisir akan terjadinya kebangkrutan.

Namun, jika mengacu pada ketentuan Bank Indonesia yang menyatakan standar ideal ROA sebesar 1,5\% maka kinerja Bank Panin Syariah sebelum dan setelah go public berada pada kondisi ideal.

\subsubsection{Return On Equity (ROE)}

Pada tabel 1 dapat terlihat bahwa nilai rata-rata (mean) rasio ROE setelah go public sebesar 6,34\% lebih kecil dibandingkan rasio ROE sebelum go public sebesar $8,06 \%$ yang artinya bahwa terdapat perbedaan penurunan nilai ratarata ROE sebesar 1,72. Persentase ini menunjukkan bahwa kemampuan Bank Panin Syariah sebelum go public dalam menghasilkan laba dari modal sendiri lebih baik dibandingkan setelah go public. Namun, apabila mengacu pada Prospektus Bank Panin Syariah yang menyebutkan bahwa 80penggunaan dana dari hasil penjualan saham akan digunakan $80 \%$ untuk pembiayaan jangka panjang, dan $20 \%$ untuk pengembangan jaringan, jadi dapat dijelaskan bahwa penurunan nilai rata-rata tersebut karena setelah go public Bank Panin Syariah baru memberikan pembiayaan pertama kepada nasabah sehingga return yang didapatkan pada tahun pertama yaitu 2014 masih sangat kecil.

Namun, jika mengacu pada ketentuan Bank Indonesia yang menyatakan standar ideal ROE sebesar 5-12\% maka kinerja Bank Panin Syariah sebelum dan setelah go public berada pada kondisi ideal.

\subsubsection{Net Interest Margin (NIM)}

Pada tabel 1 dapat terlihat bahwa nilai rata-rata (mean) rasio NIM setelah go public sebesar 5,26\% lebih kecil dibandingkan rasio NIM sebelum go public sebesar 5,46\% yang artinya bahwa terdapat penurunan nilai NIM sebesar 0,2. Persentase ini menunjukkan bahwa NIM Bank Panin Syariah sebelum go public lebih baik dibandingkan setelah go public. Sama halnya dengan fakor earnings lainnya seperti ROA dan ROE, NIM juga mengalami penurunan nilai rata-rata (mean). Namun, jika mengacu pada ketentuan Bank Indonesia yang menyatakan standar ideal NIM sebesar $>5 \%$ maka kinerja Bank Panin Syariah sebelum dan setelah go public berada pada kondisi ideal.

\subsubsection{Capital Adequacy Ratio(CAR)}

Pada tabel 1 dapat terlihat bahwa nilai rata-rata (mean) rasio CAR setelah go public sebesar $27,13 \%$ lebih besar dibandingkan rasio CAR sebelum go public sebesar $22,69 \%$ yang artinya terdapat perbedaan peningkatan rata-rata nilai CAR sebesar 4,44\%. Persentase CAR tersebut menggambarkan bahwa 
nilai CAR setelah go public lebih baik dibandingkan sebelum go public. Hal ini dikarenakan pada tahun 2014 Bank Panin Syariah melakukan go public sehingga bank mendapatkan tambahan dana dari hasil penjualan saham.Apabila jika mengacu pada ketentuan Bank Indonesia tentang kewajiban penyediaan modal minimum (KPMM) bahwa standar terbaik atau minimum CAR adalah 8\% maka kinerja Bank Panin Syariah sebelum dan setelah go public berada pada kondisi ideal karena memiliki nilai CAR diatas ketentuan standar BI.

\subsection{PENGUJIAN HIPOTESIS SEBELUM DAN SETELAH GO PUBLIC}

\subsubsection{NPF (Non Performing Financing)}

Rasio ini merupakan salah satu rasio dalam faktor risk profile pada metode RGEC yang digunakan untuk menilai risiko kredit atau pembiayaan pada suatu bank. Hasil uji statistik pada rasio NPF terdapat pada tabel 2 adalah sebagai berikut:

Tabel 2. Test Statistics NPF

\begin{tabular}{lc}
\hline & Setelah-Sebelum \\
\hline $\mathrm{Z}$ & $-.730^{\mathrm{a}}$ \\
\hline Asymp. Sig. (2-tailed) & .465 \\
\hline \multicolumn{2}{c}{ Sumber: Data primer yang telah diolah }
\end{tabular}

Berdasarkan tabel 2 pada pengujian wilcoxon, maka hasil hipotesis yang didapatkan pada pengujian NPF memiliki sig. sebesar 0,465/2 =0,2325 dengan derajat kesalahan yang sudah ditetapkan yaitu sebesar 0,05. Sehingga dapat dilihat $0,2325>0,05$. Artinya bahwa nilai sig lebih besar dibandingkan dengan derajat kesalahan sehingga $\mathrm{H}_{\mathrm{o}}$ diterima. Jadi, dapat disimpulkan bahwa kinerja NPF Bank Panin Syariah sebelum go public dan setelah go public tidak terdapat perbedaan secara signifikan. Penelitian ini konsisten dengan penelitian sebelumnya yang dilakukan oleh Yung Sen dan Lili Syafitri bahwa kinerja bank setelah go public pada rasio solvabilitas tidak berpengaruh secara signifikan.

\subsubsection{FDR (Financing to Deposit Ratio)}

Rasio ini digunakan untuk menilai tingkat likuiditas suatu bank. Hasil uji statistik pada rasio FDR terdapat pada tabel 3 adalah sebagai berikut:

Tabel 3. Test Statistics FDR

\begin{tabular}{lc}
\hline & Setelah-sebelum \\
\hline $\mathrm{Z}$ & $-.365^{\mathrm{a}}$ \\
\hline Asymp. Sig. (2-tailed) & .715 \\
\hline \multicolumn{2}{c}{ Sumber: Data primer yang telah diolah }
\end{tabular}

Berdasarkan tabel 3 pada pengujian wilcoxon, maka hasil hipotesis yang didapatkan pada pengujian FDR memiliki sig. sebesar 0,715/2 =0,3575 dengan derajat kesalahan yang sudah ditetapkan yaitu sebesar 0,05 . Sehingga dapat dilihat $0,3575>0,05$. Artinya bahwa nilai sig lebih besar dibandingkan 
dengan derajat kesalahan sehingga $\mathrm{H}_{\mathrm{o}}$ diterima. Jadi, dapat disimpulkan bahwa kinerja FDR Bank Panin Syariah sebelum go public dan setelah go public tidak terdapat perbedaan secara signifikan.Berbeda dengan penelitian sebelumnya yang dilakukan oleh Nurul Shiyam Aprila (2014) menunjukkan bahwa terdapat perbedaan yang signifikan pada rasio FDR dalam metode RGEC.

\subsubsection{ROA (Return on Asset)}

Rasio ini digunakan untuk mengukur kemampuan manajemen bank dalam memperoleh keuntungan yang dihasilkan dari rata-rata total asset bank yang bersangkutan. Hasil uji statistik pada rasio ROA terdapat pada tabel 4 adalah sebagai berikut:

Tabel 4. Test Statistics ROA

\begin{tabular}{lc}
\hline & Setelah-sebelum \\
\hline $\mathrm{Z}$ & $-.730^{\mathrm{a}}$ \\
\hline Asymp. Sig. (2-tailed) & .465 \\
\hline \multicolumn{2}{c}{ Sumber: Data primer yang telah diolah }
\end{tabular}

Berdasarkan tabel 4 pada pengujian wilcoxon, maka hasil hipotesis yang didapatkan pada pengujian ROA memiliki sig. sebesar $0,465 / 2=0,2325$ dengan derajat kesalahan yang sudah ditetapkan yaitu sebesar 0,05. Sehingga dapat dilihat $0,2325>0,05$. Artinya bahwa nilai sig lebih besar dibandingkan dengan derajat kesalahan sehingga $\mathrm{H}_{\mathrm{o}}$ diterima. Jadi, dapat disimpulkan bahwa kinerja ROA Bank Panin Syariah sebelum go public dan setelah go public tidak terdapat perbedaan secara signifikan.Hasil penelitian ini didukung oleh penelitian yang dilakukan Yung Sen dan Lili Syafitri yaitu Analisis Perbedaan Kinerja Keuangan Sebelum dan Sesudah IPO pada Perusahaan Go Public di BEI. Hasilnya menunjukkan bahwa tidak terdapat perbedaan yang signifikan pada rasio ROA sebelum dan setelah IPO.

\subsubsection{ROE (Return On Equity)}

Rasio ini digunakan untuk mengukur kemampuan manajemen bank dalam mengelola modal yang tersedia untuk menghasilkan laba setelah pajak. Hasil uji statistik pada rasio ROE terdapat pada tabel 5 adalah sebagai berikut:

Tabel 5. Test Statistics ROE

\begin{tabular}{lc}
\hline & Setelah-sebelum \\
\hline $\mathrm{Z}$ & $-.730^{\mathrm{a}}$ \\
\hline Asymp. Sig. (2-tailed) & .465 \\
\hline \multicolumn{2}{c}{ Sumber: Data primer yang telah diolah }
\end{tabular}

Berdasarkan tabel 5 pada pengujian wilcoxon, maka hasil hipotesis yang didapatkan pada pengujian ROE memiliki sig. sebesar 0,465/2 =0,2325 dengan derajat kesalahan yang sudah ditetapkan yaitu sebesar 0,05 . Sehingga dapat dilihat $0,2325>0,05$. Artinya bahwa nilai sig lebih besar dibandingkan dengan derajat kesalahan sehingga $\mathrm{H}_{\mathrm{o}}$ diterima. Jadi, dapat disimpulkan bahwa kinerja ROE Bank Panin Syariah sebelum go public dan setelah go 
public tidak terdapat perbedaan secara signifikan. Konsisten dengan penelitian sebelumnya yang dilakukan oleh Adhisyafitri Evalina Ikhsan hasilnya menunjukkan bahwa tidak terdapat pebedaan yang signifikan terhadap kinerja perusahaan sebelum dan sesudah IPO.

\subsubsection{NIM (Net Interest Margin)}

Rasio ini digunakan untuk mengukur kemampuan manajemen bank dalam mengelola aktiva produktifnya untuk menghasilkan pendapatan bunga bersih. Hasil uji statistik pada rasio NIM terdapat pada tabel 6 adalah sebagai berikut:

Tabel 6. Test Statistics NIM

\begin{tabular}{lc}
\hline & Setelah-sebelum \\
\hline $\mathrm{Z}$ & $-.365^{\mathrm{a}}$ \\
\hline Asymp. Sig. (2-tailed) & .715 \\
\hline \multicolumn{2}{c}{ Sumber: Data primer yang telah diolah }
\end{tabular}

Berdasarkan tabel 6 pada pengujian wilcoxon, maka hasil hipotesis yang didapatkan pada pengujian NIM memiliki sig. sebesar 0,715/2 =0,3575 dengan derajat kesalahan yang sudah ditetapkan yaitu sebesar 0,05. Sehingga dapat dilihat $0,3575>0,05$. Artinya bahwa nilai sig lebih besar dibandingkan dengan derajat kesalahan sehingga $\mathrm{H}_{\mathrm{o}}$ diterima. Jadi, dapat disimpulkan bahwa kinerja NIM Bank Panin Syariah sebelum go public dan setelah go public tidak terdapat perbedaan secara signifikan.Serupa dengan penelitian yang dilakukan oleh Iqbal (2013) menunjukkan bahwa tidak terdapat perbedaan yang signifikan pada rasio Net Interest Margin.

\subsubsection{CAR (Capital Adequacy Ratio)}

Rasio ini merupakan rasio kewajiban modal minimum yang harus dimiliki oleh bank.Hasil uji statistik pada rasio CAR terdapat pada tabel 7 adalah sebagai berikut:

Tabel 7. Test Statistics CAR

\begin{tabular}{lc}
\hline & Setelah-sebelum \\
\hline $\mathrm{Z}$ & $-1.826^{\mathrm{a}}$ \\
\hline Asymp. Sig. (2-tailed) & .068 \\
\hline \multicolumn{2}{c}{ Sumber: Data primer yang telah diolah }
\end{tabular}

Berdasarkan tabel 7 pada pengujian wilcoxon, maka hasil hipotesis yang didapatkan pada pengujian CAR memiliki sig. sebesar 0,034 dengan derajat kesalahan yang sudah ditetapkan yaitu sebesar 0,05 . Sehingga dapat dilihat $0,034<0,05$. Artinya bahwa nilai sig lebih kecil dibandingkan dengan derajat kesalahan sehingga $\mathrm{H}_{\mathrm{o}}$ ditolak. Jadi, dapat disimpulkan bahwa kinerja CAR Bank Panin Syariah sebelum go public dan setelah go public terdapat perbedaan secara signifikan. Berbeda dengan penelitian yang dilakukan oleh Sabbina (2013) yang hasilnya menunjukkan bahwa tidak terdapat perbedaan yang signifikan pada rasio CAR. 


\subsection{PENILAIAN TERHADAP GCG (GOOD CORPORATE GOVERNANCE)}

Good Corporate Governance merupakan salah satu komponen penilaian dalam metode RGEC dan bukan merupakan penilaian terhadap kinerja keuangan bank. Oleh karena itu, laporan pelaksanaan GCG dibuat terpisah dari laporan keuangan.

Berdasarkan Laporan pelaksanaan GCG Bank panin syariah periode 2013 dan 2014, bahwa pelaksanaan GCG pada Bank Panin Syariah periode sebelum go public mendapatkan skor sebesar 1,35 sedangkan pelaksanaan GCG Bank Panin Syariah setelah go public mendapatkan skor 1,40. Secara umum dapat disampaikan bahwa berdasarkan hasil self assessment terhadap pelaksanaan Good Corporate Governance tahun 2013 dan tahun 2014, bank memperoleh predikat sangat baik, meskipun terdapat perbedaan pada bobot nilai sebesar 0,05 . Perbedaan tersebut dapat dilihat pada faktor kelima ari pelaksanaan GCG Bank Panin Syariah, yaitu pelaksanaan prinsip syariah dalam kegiatan penghimpunan dana dan penyaluran dana serta pelayanan jasa.

Adapun hasil dari analisis deskriptif pelaksanaan GCG Bank Panin Syariah memperlihatkan bahwa setelah adanya go public menurunkan bobot nilai pada pelaksanaan prinsip syariah dalam kegiatan penghimpunan dana dan penyaluran dana serta pelayanan jasa, kemungkinan dari penurunan tersebut karena Bank Panin Syariah harus menyesuaikan diri dengan kondisi yang baru dimana terdapat perubahan dari sisi capital maupun dari sisi kepemilikan saham. Namun, meskipun terjadi penurunan nilai, hal ini tidak terlalu berdampak pada kinerja Bank Panin Syariah, karena selain penurunan nilai tersebut sangat kecil, pelaksanaan GCG Bank Panin Syariah setelah go public juga mendapatkan predikat sangat baik.

\section{SIMPULAN}

Hasil uji statistik non parametrik wilcoxon testpada kinerja keuangan Bank Panin Syariahmenunjukkan terdapat perbedaan yang signifikan pada rasio CAR, sedangkan pada rasio rasio NPF, FDR, ROA, ROE, dan NIM tidak menunjukkan perbedaan yang signifikan terhadap kinerja Bank Panin Syariah sebelum dan setelah go public, yaitu:

1. Faktor R (risk profile) yaitu rasio NPF dan FDR. Berdasarkan hasil pengujian terhadap rasio NPF (Non Performing Financing) tidak terdapat perbedaan yang signifikan pada kinerja Bank Panin Syariah sebelum dan setelah go public yaitu dengan melihat nilai signifikansi 0,2325 lebih besar dari derajat kesalahan 0,05. Dan pada rasio FDR (Financing to Deposit Ratio) tidak terdapat perbedaan yang signifikan pada kinerja Bank Panin Syariah sebelum dan setelah go public yaitu dengan melihat nilai signifikansi 0,3575 lebih besar dari derajat kesalahan 0,05. 
2. Faktor G (Good Corporate Governance) yaitu dilihat dari laporan pelaksanaan GCG Bank Panin Syariah dari hasil self assessment terhadap pelaksanaan Good Corporate Governance tahun 2013 atau sebelum go public memperoleh predikat sangat baik dengan nilai komposit 1,35. Dan pada tahun 2014 atau setelah go public, bank memperoleh predikat sangat baik dengan nilai komposit sebesar 1,40. Perbedaan 0,05 tidak berpengaruh besar karena perbedaan nilai tersebut cenderung sangat kecil.

3. Faktor E (Earnings) yaitu rasio ROA, ROE, NIM. Berdasarkan hasil pengujian terhadap rasio ROA (Return On Asset) tidak terdapat perbedaan yang signifikan pada kinerja Bank Panin Syariah sebelum dan setelah go public yaitu dengan melihat nilai signifikansi 0,2325 lebih besar dari derajat kesalahan 0,05. Dan pada rasio ROE (Return On Equity) tidak terdapat perbedaan yang signifikan pada kinerja Bank Panin Syariah sebelum dan setelah go public yaitu dengan melihat nilai signifikansi 0,2325 lebih besar dari derajat kesalahan 0,05. Serta pada rasio NIM (Net Interest Margin) juga tidak terdapat perbedaan yang signifikan pada kinerja Bank Panin Syariah sebelum dan setelah go public yaitu dengan melihat tingkat signifikansi 0,3575 lebih besar dari derajat kesalahan 0,05.

4. Faktor C (Capital) yaitu rasio CAR (Capital Adequacy Ratio) terdapat perbedaan yang signifikan pada kinerja Bank Panin Syariah sebelum dan setelah go public yaitu dengan melihat tingkat signifikansi 0,034 lebih besar dari derajat kesalahan 0,05.

Perbedaan kinerja Bank Panin Syariah sebelum dan setelah go public dapat dilihat dari nilai rata-rata (mean) pada rasio NPF, FDR, ROA, ROE, NIM, dan CAR. Rasio yang mengalami peningkatan atau berpengaruh positif terhadap kinerja bank adalah rasio NPF, FDR, dan CAR, sedangkan rasio yang mengalami penurunan adalah rasio yang terdapat pada faktor earnings, yaitu ROA, ROE, dan NIM.

\section{DAFTAR PUSTAKA}

Ikhsan, Adhisyahfitri Evalina. "Analisis Kinerja Perusahaan: Sebelum dan Setelah Initial Public Offering di Bursa Efek Indonesia", Jurnal Universitas Syiah Kuala

Iqbal, Muhammad. 2013. "Analisis Perbandingan Kinerja Keuangan BUS, UUS, dan Konvensional dengan metode CAMELS", Skripsi: UIN Jakarta

Jumingan. 2006. Analisis Laporan Keuangan. Jakarta: Bumi Aksara

Kasmir. 2010. Analisis Laporan Keuangan. Jakarta: PT Rajawali Press 
Kasmir. 2009. Bank dan Lembaga Keuangan Lainnya. Jakarta: Rajawali Pers.

Kurniawan, Adhi. 2012. "Wilcoxon Sign Rank Test". https//adhikurniawan.files. wordpress.comdiakses pada 1 Desember 2015

Kurniawan, Albert. 2011. "SPSS Serba-Serbi Analisis Statistika Dengan Cepat dan Mudah". Jasakom

Lasta, Heidy Arrvida dkk., 2014. "Analisis Tingkat Kesehatan bank dengan menggunakan pendekatan RGEC", Jurnal Administrasi Bisnis, Universitas Brawijaya

Muhammad. 2005. Manajemen Dana Bank Syariah, Yogyakarta: Ekonisia

Mutia, Noor. 2014. "Penilaian Tingkat Kesehatan Bank: CAMEL dan RGEC" noormutia.blogspot.com/2014/04/blk5.html diakses pada 14 November 2015

Rifai, Veithzal dan Andria Permata Veithzal. 2008. Islamic Financial Management, Jakarta: PT Raja Grafindo Persada

Wardani, S. L. 2009. "Efektifitas Jaminan Perseorangan (Borgtocht) Apabila Debitur Wanprestasi Pada Bank Jateng Cabang Pemuda Semarang”. Tesis Undip Semarang

Surat Edaran Bank Indonesia No.13/24/DPNP

Surat Edaran Bank Indonesia No 6/23/DPNP

Undang-Undang Nomor 10 Tahun 1998

UU Nomor 21 tahun 2008

Peraturan Otoritas Jasa Keuangan Nomor 8/POJK.03/2014 